As a result of these and other experiments under varying conditions, it is concluded that the maximum formation of porphyrins by yeast is associated with great cellular activity, and the amounts here found are much greater than those resulting by changes occurring after death of the cells.

Intracellular poisons, such as sodium fluoride and even 1 per cent toluene, caused a rapid decline in the porphyrin content by slowing down the metabolism. Samples of brewer's wort collected at intervals during fermentation exhibited the same changes as with ammonium carbonate alone, with the accumulation of $284 \mu \mathrm{gm}$. porphyrin per gram of original yeast at the end of the active fermentation period (72 hr.); but all this pigment was used up in the ensuing forty-eight hours.

Fractionation of the porphyrins showed that traces only of proto- and deutero-porphyrins were present, insufficient for identification of isomers. Coproporphyrin comprised in most instances a mixture of isomers I and III which were determined by ultra-violet fluorimetry and identified by crystallography and melting point of the methyl esters. The relative proportions of the two isomers varied within wide limits; it is interesting to see that coproporphyrin I predominates when sufficient carbohydrate for respiration is present, but in conditions of carbohydrate starvation (after 66 hours, Table 2) coproporphyrin III appears in large amounts, and is responsible for practically all the porphyrin present under these conditions. Thus the isomers III or I may predominate in yeast according to the nature of the nutrient medium.

Further investigations are being carried out to determine if, and how, these changes are related to cytochrome synthesis and rate of respiration.

J. E. КENCH.

J. F. WILKINSON.

Department of Clinical Investigations and Research,

Manchester Royal Infirmary.

${ }^{1}$ Rimington, C., Nature, 151, 393 (1943).

\section{Geology of the Punjab Salt Range}

WIтH reference to Sir Cyril Fox's interesting article under the above heading ${ }^{1}$, I wish to make certain comments. I think that nobody maintains that the Kohat-Potwar Saline Series is of post-Eocene age. As Prof. Sahni says", his "fossil evidence is consistent with any geological age from the Lower Tertiary to the recent. But since on stratigraphical grounds the Saline Series cannot be younger than early Tertiary, the conclusion is that it is of Eocene age". I have shown ${ }^{3}$ that the latest marine beds of that region are of Upper Khirthar (Auversian) age; so there were apparently no marine waters to desiccate, in that region, after the Eocene.

Again, aridity alone seems to be stressed when discussing the production of thick salt deposits. Thus Sir Cyril says (p. 259) that "an arid period almost certainly prevailed ... in early Cambrian or preCambrian times, which, according to $\mathrm{Mr}$. Gee, ... . was soon after the rock-salt deposits had formed in the Punjab area"; and he adds that "there is little such evidence in support of an Eocene age for these deposits". But the main essentials for producing thick salt deposits are topographical rather than climatical. So far as climate is concerned, it is only necessary that evaporation should dispose of all waters in, or entering, the area concerned; but the production of an excessive accumulation of salt is not a simple matter-it demands rare topographical conditions like, for example, those now existing in the Dead Sea region, or those on the eastern borders of the Caspian Sea (Karaboghaz Gulf), etc. ${ }^{4}$. Nobody has yet attempted to show that the pre-Cambrian topography of the Kohat-Potwar region was of one of these exceptional kinds.

On the other hand, I have shown ${ }^{5}$ that topographical conditions of such a kind did apparently exist, in that region, in Lower Chharat (basal Khirthar, or earliest Middle Eocene) times. So I must point out that Dr. West's summary of papers ${ }^{6}$, to which Sir Cyril refers (p. 258), is incomplete in this respect. For it was not until 1936 that I finished surveying the Eocene beds of the Kohat district, and realized that Laki (Lower Eocene) elements disappear from below upwards to the west, and do not exist in Waziristan ${ }^{7}$. French geologists, working from the opposite (Afghanistan) side, soon afterwards made corresponding observations ${ }^{8}$, showing that what I call a "Waziristan ridge" rose at the close of Ranikot (Palæocene) times. The emergence of this ridge must have greatly reduced the marine connexions of the Kohat-Potwar basin, which were yet more fully severed at the close of Laki times ${ }^{\theta}$. It is obvious that along the southern borders of that basin-and especially at their western extremity, where spasmodic marine incursions still occurred even in Lower Chharat times ${ }^{10}$ - topographical conditions would have favoured the production of large accumulations of salt. (Waters were, in fact, trapped; and trapped in such a manner as to satisfy the theory of G. Bischof and C. Ochsenius regarding one way of forming thick salt deposits ; cf. F. W. Clarke, as above ${ }^{4}$.) This I briefly indicated in my last letter, the main point of which is apparently missed by those who refer to it ${ }^{11}$ only to stress Mr. Gee's change of mind as to whether the fossils which I identified for him had, or had not, been found by him in situ.

To discuss further points would unduly extend this letter; so I merely emphasize, here, the need for considering the topographical essentials for producing thick salt deposits. Whether or not suitable conditions existed in pre-Cambrian times (a matter which seems never to have been worked out, and may not be capable of demonstration) I can scarcely agree that they did not exist in Eocene times. The Eocene is the one period when known structural evidence indicates that they did exist.

\section{Grant Institute of Geology, \\ University of Edinburgh. March 19.}

${ }^{1}$ Nature, 155, 258 (1945).

${ }^{2}$ Proc. Nat. Acad. Sci. Ind., 14, 86 (1944).

s Quart. J. Geol. Soc. Lond., 96, 199 (1940); 99, 63 (1943).

"Cf. Clarke, F. W., "Data of Geochemistry", 215ff (1920).

s Nature, 154, 53 (1944), etc.

- Curr. Sci., 3, No. 9 (March 1935).

${ }^{7}$ Davies, L. M., C.R. Soc. Géol. France, 2, 22 ; 15, 294 (1938) ; Nature, 142, 296 (1938), etc. For diagram showing east-to-west succeșsion 142, 296 (1938), etc. For diagram showing east-to-west

- Cizancourt, Mme. de, Mém. Soc. Géol. France, N.S., 17, Fasc. 1, Mém., 39, 14 (1938).

- See palæogeographical diagrams, Proc. Sixth Pac. Sci. Congress (1939), $2,489,494$, etc. (1940). The delta of the proto-Kurram
river was shifted eastwards, as its contemporary deposits show, by the emergence of this ridge, and may have further tended to block the marine connexion. Wind-rounded sand-grains (found by the marine connexion. Wind-rounded sand-grains (found by local aridity than some suppose to have existed at that time.

${ }^{10}$ Cox, L. R., Ann. Mag. Nat. Hist., ii, 1, 172 (1938).

11 Nature, 155, 267 (1945). 